\title{
A seafloor crater in the German Bight and its effects on the benthos
}

Received: 12 June 1998 / Accepted:16 September 1998

\begin{abstract}
In 1963 a deep crater was formed about $65 \mathrm{~m}$ below sea level in the western part of the German Bight, due to a gas eruption caused by drilling carried out from the platform 'Mr. Louie'. The study area is situated in a sandy to muddy bottom area inhabited by an Amphiura filiformis association (sensu Salzwedel et al. 1985). The crater, sometimes called 'Figge-Maar', functions as a sediment trap, concentrating particles and organisms from the water column, thus leading to extreme sedimentation rates of about $50 \mathrm{~cm}$, on average, per year. Crater stations, compared with stations situated in the vicinity, show enrichments of juveniles. Echinoderms, especially the subsurface-dwelling heart urchin Echinocardium cordatum and ophiuroids are responsive to enrichment. Other species that are typical of the Amphiura filiformis association are shown to be unable to cope with the special conditions in the crater.
\end{abstract}

Key words North Sea $\cdot$ Macrobenthos .

Benthic-pelagic coupling $\cdot$ Sediment trapping ·

Community structure

\section{Introduction}

The study area is situated around a crater 20 miles west of the island of Helgoland in the German Bight (Fig. 1). The crater was formed in 1963 by a carbon dioxide eruption after a gas bubble had been hit during explorative drilling down to about $3000 \mathrm{~m}$ below the sea bed. This anthropogenic crater is an artificial structure in an area typically $34 \mathrm{~m}$ deep, the bottom of which is inhabited by an Amphiura filiformis association (Salzwedel et al. 1985; Thatje and Gerdes 1997). This paper is an analysis

This is Publication No. 1422 of the Alfred-Wegener-Institute

S. Thatje $(-$ D. Gerdes $\cdot$ E. Rachor

Alfred-Wegener-Institute for Polar and Marine Research,

Columbusstr., D-27568 Bremerhaven, Germany

e-mail: sthatje@awi-bremerhaven.de of the crater's influence on the benthic regime. The questions to be answered are:

- How are the sedimentation rates in the crater?

- How is the benthic association in the crater structured compared with the surrounding A. filiformis association?

- Are meroplanktic larvae enriched in the crater?

- What is the fate of new colonizers in the crater?

- What is the effect of sedimentation on the benthic community in the crater?

There is evidence that this bottom anomaly affects the bentho-pelagic coupling by acting like a sediment trap, thus concentrating seston and plankton organisms. Even in the intensively investigated German Bight few studies have examined interaction between the pelagic and benthic regime. In the past, pelagic studies (Rees 1954; Dippner 1980) and studies of the benthos (Hagmeier 1925; Reineck et al. 1968; Stripp 1969; Salzwedel 1985; Thatje and Gerdes 1997) were performed separately, although there is general agreement that such benthicpelagic studies are needed to understand the whole ecosystem and changes in the benthic regime (e.g. Bosselmann 1989).

\section{Materials and methods}

Area of investigation

The area under investigation (about $750 \mathrm{~km}^{2}$ ) is situated in the vicinity of the Pleistocene Elbe River valley in the western part of the A. filiformis association, which is one of the most extended associations in the southern North Sea. In total 49 samples were obtained at 21 benthos stations in 1992, 1995 and 1996; 7 stations were situated directly in the "Figge-Maar", as the crater is often called (see Table 1).

\section{Sampling and sample treatment}

Echo sounder data (Hydrosweep, STN Atlas Electronic) from 1981, 1982 and 1995 provided the basis for a description of topographic changes (see Fig. 2). In August 1995, 18 samples were ob- 
Fig. 1 Study area in the German Bight

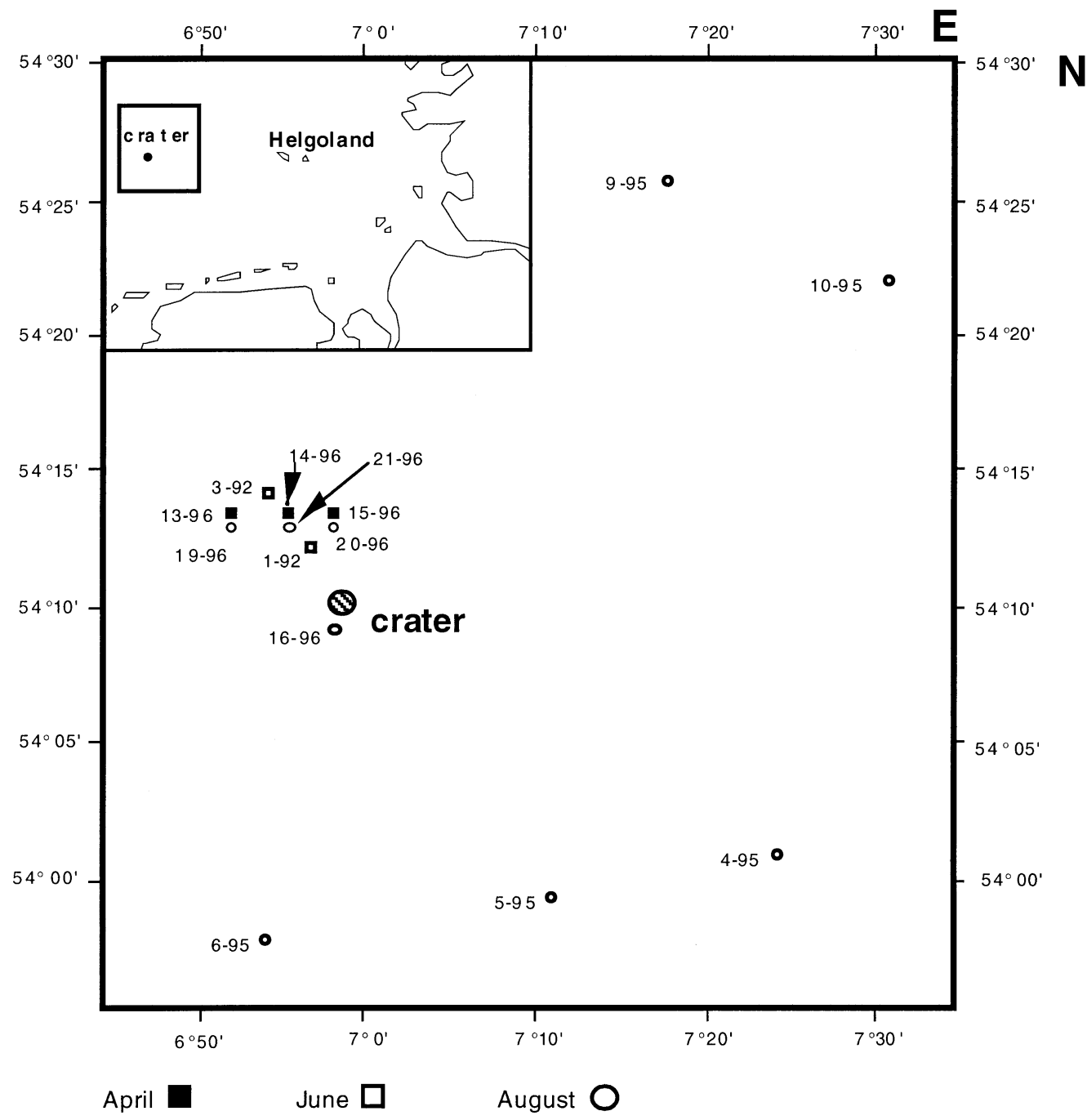

Seven stations are situated in the crater:

St. Nos. 2-92; 7-95; 8-95;11-96;12-96;17-96;18-96

Table 1 Station list. Number of sediment samples in brackets. $v$. . van-Veen; $m . c$. multibox corer; $c$ crater stations

\begin{tabular}{|c|c|c|c|c|c|c|c|}
\hline $\begin{array}{l}\text { Station } \\
\text { No. }\end{array}$ & Date & Ship/station & $\begin{array}{l}\text { Longitude } \\
\text { (N) }\end{array}$ & $\begin{array}{l}\text { Latitude } \\
\text { (E) }\end{array}$ & $\begin{array}{l}\text { Depth } \\
\text { (m) }\end{array}$ & Samples & Gear \\
\hline St. 1 & 3.6 .92 & VH 101 & $54^{\circ} 12.0$ & $06^{\circ} 57.0$ & 34.4 & 3 & v.V. \\
\hline St. 3 & 3.6 .92 & VH 106 & $54^{\circ} 14.0$ & $06^{\circ} 54.0$ & 34 & 2 & v.V. \\
\hline St.4 & 1.8 .95 & MG 3 & $54^{\circ} 01.5$ & $07^{\circ} 24.8$ & 32 & 2 & m.c. \\
\hline St.5 & 1.8 .95 & MG 4 & $53^{\circ} 58.8$ & $07^{\circ} 11.2$ & 29 & $3(3)$ & m.c. \\
\hline St.6 & 1.8 .95 & MG 5 & $53^{\circ} 57.1$ & $06^{\circ} 54.2$ & 27 & $3(3)$ & m.c. \\
\hline St. 9 & 1.8 .95 & MG 8 & $54^{\circ} 25.83$ & $07^{\circ} 18.4$ & 31 & $3(3)$ & m.c. \\
\hline St. 10 & 1.8 .95 & MG 9 & $54^{\circ} 22.5$ & $07^{\circ} 31.9$ & 27 & 3 & m.c. \\
\hline St. 11 (c) & 18.4 .96 & VH 119 a & $54^{\circ} 10.0$ & $06^{\circ} 58.3$ & 48 & 2 & v.V. \\
\hline St. 12 (c) & 18.4 .96 & VH $119 \mathrm{~b}$ & $54^{\circ} 10.0$ & $06^{\circ} 58.5$ & 39 & 2 & v.V. \\
\hline St. 13 & 18.4 .96 & VH $120 a$ & $54^{\circ} 13.5$ & $06^{\circ} 52.1$ & 34 & 2 & v.V. \\
\hline St. 14 & 18.4 .96 & VH $120 b$ & $54^{\circ} 13.5$ & $06^{\circ} 55.1$ & 34 & 2 & v.V. \\
\hline St. 20 & 26.8 .96 & VH 544 & $54^{\circ} 13.5$ & $06^{\circ} 55.0$ & 33 & 2 & v.V. \\
\hline St. 21 & 26.8 .96 & VH 545 & $54^{\circ} 13.5$ & $06^{\circ} 52.0$ & 33 & 2 & v.V. \\
\hline
\end{tabular}


Fig. 2 View of the 'FiggeMaar' crater, based on echosound data, August 1995

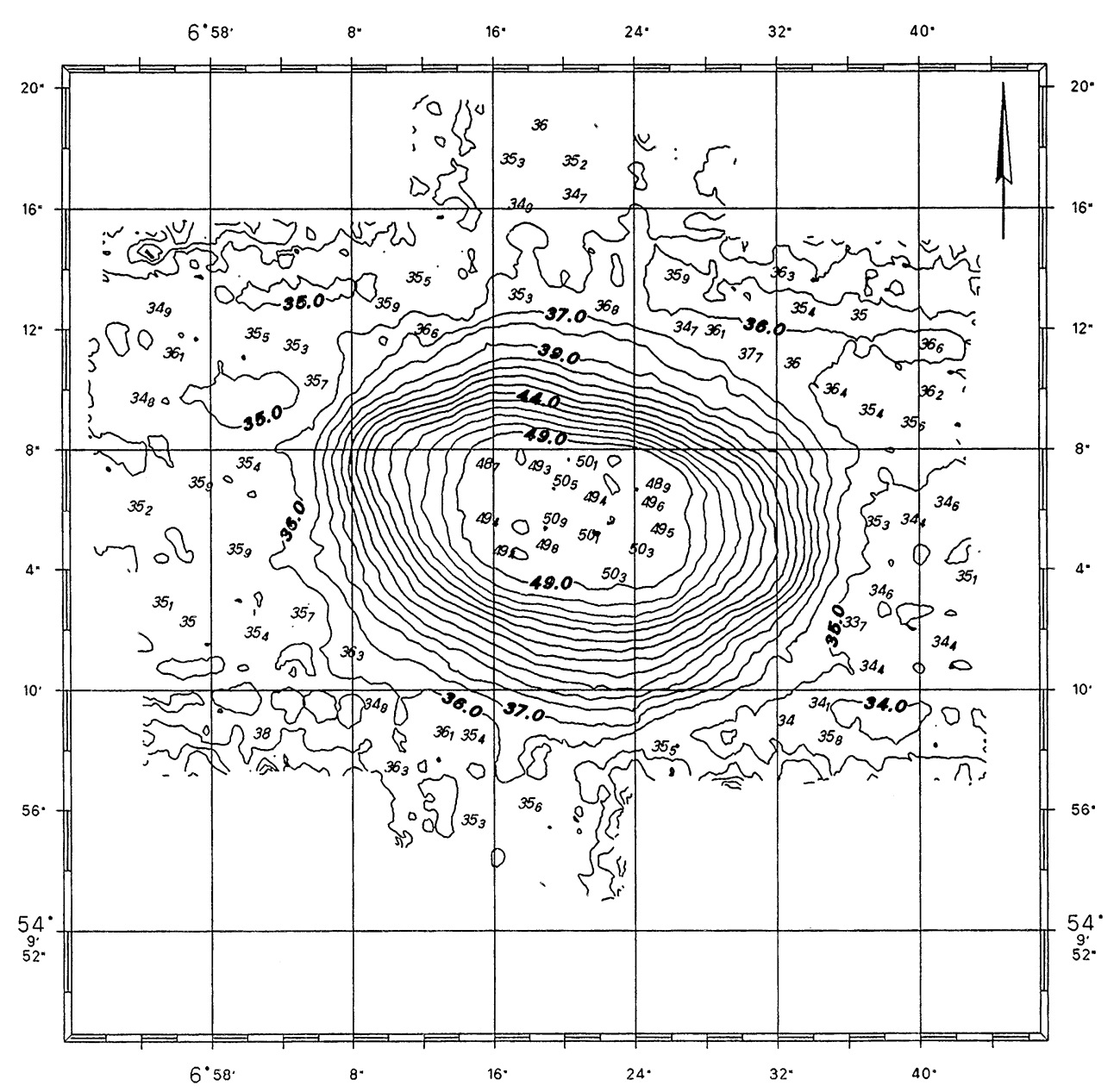

ATLAS HYDROSWEEP

FIGGE-LOCH NORDSEE

WEGA BSH

AUGUST 1995

MABSTAB 1:5000 tained by two hauls at two crater stations with a multibox corer (each box covers $0.024 \mathrm{~m}^{2}$ ); 5 samples were considered for macrofauna analyses, whereas the rest were used for surface sediment studies (upper $3 \mathrm{~cm}$ ). Together with three other sediment stations, which were also taken with the multibox corer (three samples each) in the crater's vicinity, these samples provided the basis for a detailed sediment analysis (see Müller 1964; Thatje and Gerdes 1997). Shear-stress measurements were performed with a Haake viscosimeter (Oebius 1983) in order to compare the sediment characteristics in the crater and its vicinity.

In 1992 and 1996, macrobenthos samples were taken with a van Veen grab (covening $0.1 \mathrm{~m}^{-2}$ ) at 14 stations, 5 of which were situated in the crater. Biological samples were sieved over $0.5-\mathrm{mm}$ mesh size and preserved in $4 \%$ hexamethylentetramine-buffered formalin prior to sorting in the laboratory. Benthic organisms were mainly identified to species level or eight taxonomic groups.

Biomass was determined as total wet weight. For the clustering procedure with the software package PRIMER (Clarke and Warwick 1994), all species and taxonomic groups were considered with their abundances; colonial hydrozoans were used as one animal.

\section{Results}

\section{Structure of the crater}

The bottom crater of the 'Maar' is about $400 \mathrm{~m}$ wide. It resulted from a carbon dioxide eruption during explorative drilling in 1963. First recorded depths of the crater were $65 \mathrm{~m}$ below sea level (Figge, personal communication), while the surrounding area is around $34 \mathrm{~m}$ deep (Fig. 2). Since our first investigation in 1981, depth in the crater decreased from $56 \mathrm{~m}$ to around $48 \mathrm{~m}$. Accordingly, the structure of the crater influences sedimentation rates and hence the sediment composition (Fig. 3).

\section{Sediment composition}

Differences in the sediment composition inside the crater and the shallower surroundings in 1995 are shown in 
Fig. 3 Left Sediment composition, August 1995. Right Composition of sand fractions (mm), August 1995

Fig. 4A-D Cluster dendrograms on the basis of numerical abundance; $c$ Crater

Fig. 5 Composition of macrozoobenthos (mean abundances) inside (A) and outside (B) the crater

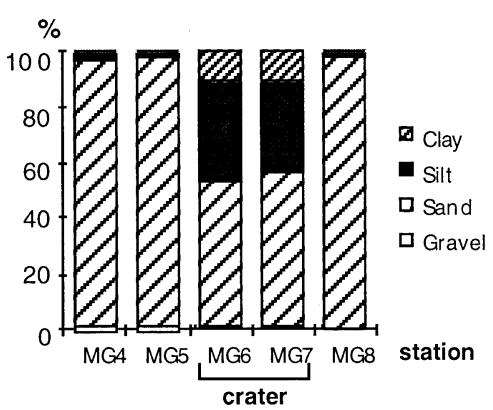

\section{A: June 1992}

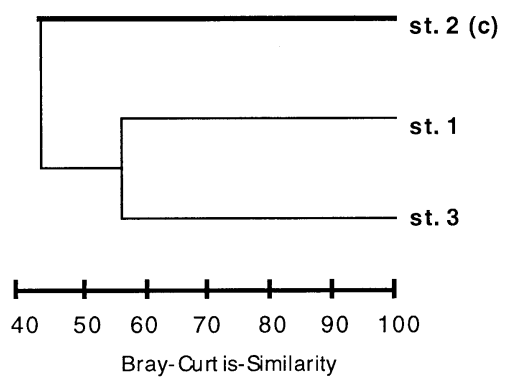

\section{C: April 1996}

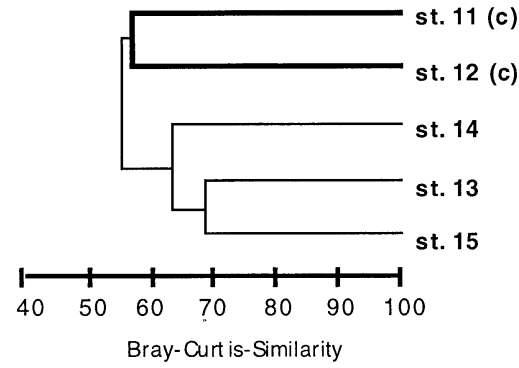

A

inside

Station Nos. $2 ; 7 ; 8 ; 11 ; 12 ; 17 ; 18$ Station Nos. $1 ; 3-6 ; 9-10 ; 13-16 ; 19-21$ $\mathrm{n}=7$ $n=14$

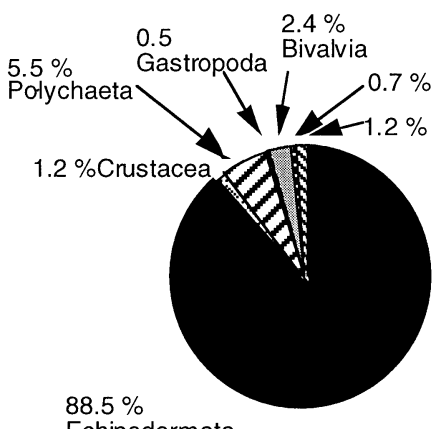

Echinodermata

Hydrozoa are present

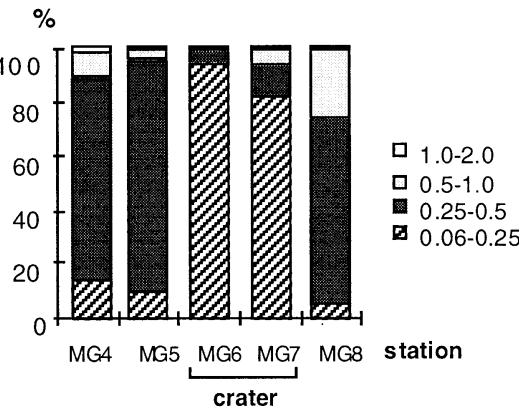

\section{B: August 1995}

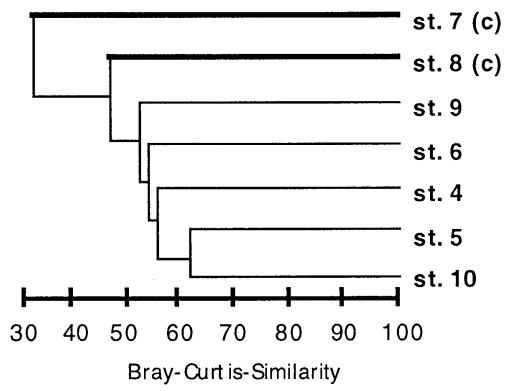

D: August 1996

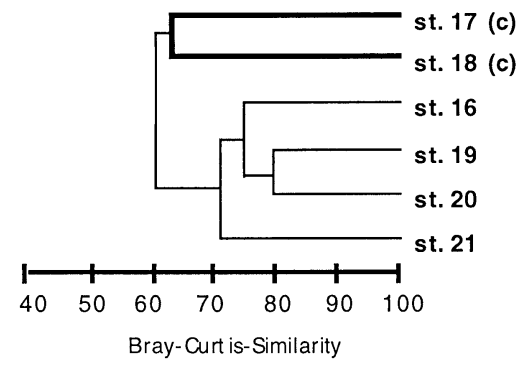

B outside 
Fig. 6A-D Comparison of echinoderm fractions (ind. $\mathrm{m}^{-2}$ ) in the crater and in its vicinity. Numbers above the bars represent total abundance values of the fraction and number of adults (x). Juv. A. filiformis $<3$ $\mathrm{mm}$ in disc diameter; juv. $\mathrm{Op}$ hiura sp. $<2 \mathrm{~mm}$ in disc diameter; juv. E. cordatum $<5 \mathrm{~mm}$ in disc diameter; Asterias rubens $<2 \mathrm{~mm}$ in total. (C According to Thatje and Gerdes 1997)
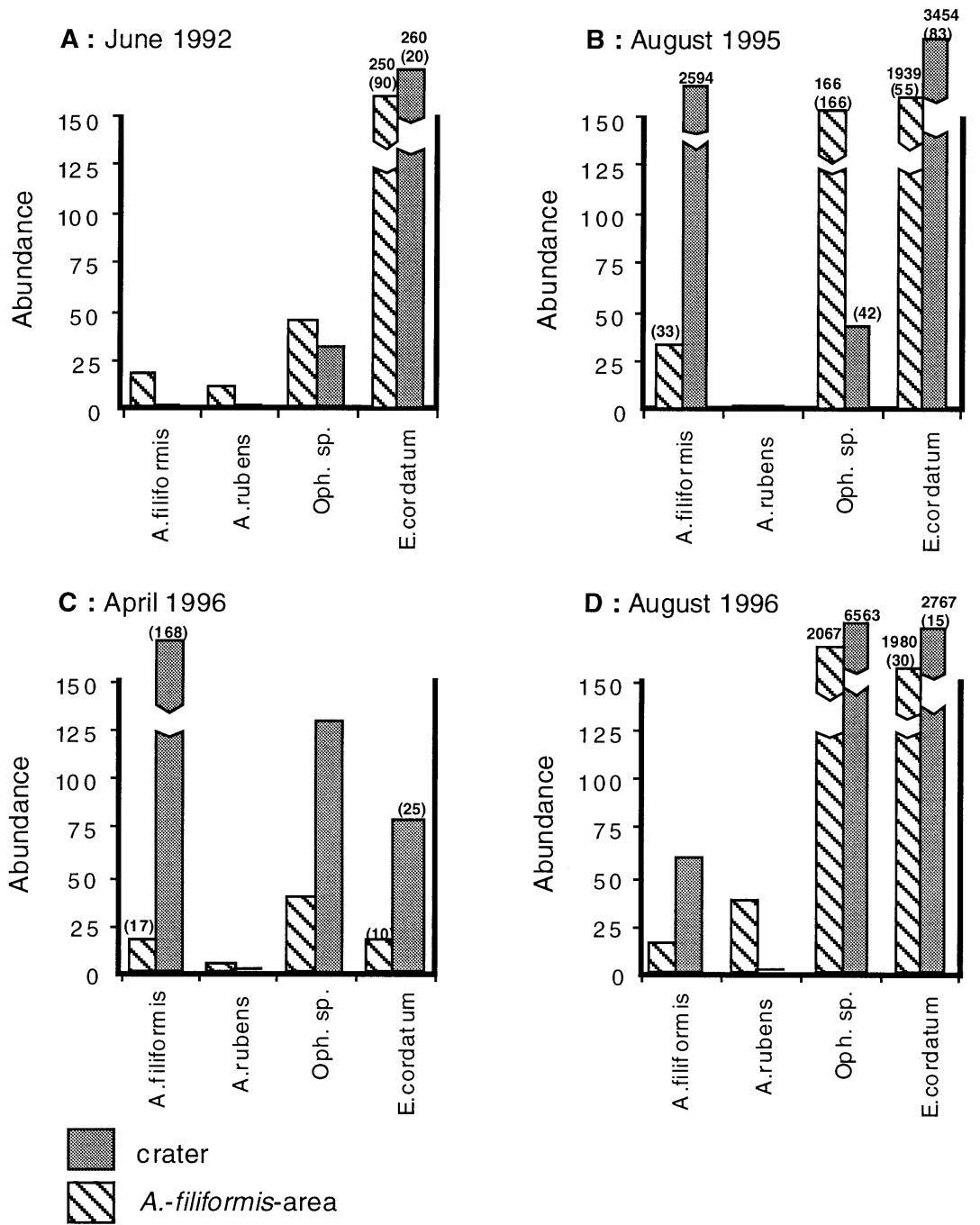

Fig. 3 left. The silt fraction in the crater is about $30 \%$, in contrast to the surroundings where this fraction was almost negligible. There were also significantly higher proportions of small particle sizes in the sand fraction (Fig. 3 right). Average shear stress was much lower in the crater $(0.72 ; \mathrm{SD} \pm 0.78)$ than at the surrounding stations (7.44; $\mathrm{SD} \pm 0.99)$, indicating the dominance of small particles and a high water content as well.

\section{Biology}

Cluster analyses showed that all crater stations were clearly separated from stations situated in the A. filiformis association area, with the exception of the slope station no. 8 in August 1995 (Fig. 4).

Comparison of the composition of the macrozoobenthos in and outside the crater reveals distinct differences (Fig. 5). The overall mean abundance outside is lower (4738 ind. $\mathrm{m}^{-2}$ ) compared to that inside (5204 ind. $\mathrm{m}^{-2}$ ), the same as for biomass, which is lower outside $(214 \mathrm{~g}$ $\mathrm{m}^{-2}$ ) than inside $\left(487 \mathrm{~g} \mathrm{~m}^{-2}\right)$. Crater stations are characterized by an extremely high dominance of echinoderms
(88.5\%), twice that of the stations outside (44.2\%), with the exception of Asterias rubens, which was only found in the vicinity of the crater. The high biomass value in the crater is due to the frequent occurrence of the heart urchin E. cordatum, which accounts for about $82 \%$ of the total biomass there. In contrast, polychaetes outside the crater had an abundance seven times that of inside, with $38.8 \%$ being long-lived sedentaria, such as L. conchilega, which are not as important in the crater $(5.1 \%$ of the polychaete fraction). Seventeen species from the vicinity were never found in the crater (Table $2 ; 17 \%$ of all occurring species).

With regard to the bivalves, only short-lived forms, such as Montacuta ferruginosa, Mysella bidentata and Abra alba, were found in the crater, together with some juveniles of Spisula subtruncata. Specimens of the decapod Callianassa subterranea occurred regularly in the subsurface of muddy sediments in the A. filiformis association, but were absent in the crater. Phoronida contribute 9.3\% of the macrobenthic composition outside as compared to $1.2 \%$ inside the crater. Some groups, such as Acrania, Sipunculida, Ostracoda and Pantopoda, occurring seldomly in the vicinity, were absent in the crater. 
Table 2 Species/taxonomic groups found only in the crater or in its vicinity

\begin{tabular}{ll}
\hline Crater taxon & Crater vicinity taxon \\
\hline Cumopsis longipes & Cultellus pellucidus \\
Polydora pulchra & Ensis siliqua \\
& Thyasira flexuosa \\
Venus striatula & Capitella capitata \\
& Harmothoe lunulata \\
Magelona papillicornis & Owenia fusiformis \\
Polydora pulchra \\
Golfingia sp. \\
Ostracoda \\
Bodotria arenosa \\
Pseudocuma longicornis \\
Corystes cassivelaunus \\
Callianassa subterranea \\
Asterias rubens \\
Branchiostoma lanceolatum
\end{tabular}

In August 1995 and again in 1996, echinoderms, especially juveniles of E. cordatum and A. filiformis, had increased in abundance inside the crater (Fig. 6), while the compared areas were quite similar in June 1992.

In 1995, at station no. 7 high abundances of juvenile E. cordatum (685 ind. $\mathrm{m}^{-2}$ ) and A. filiformis (4856 ind. $\mathrm{m}^{-2}$; corresponding to $92 \%$ of the total abundance), were much higher than the overall means in the A. filiformis association area (E. cordatum: 38 ind. $\mathrm{m}^{-2}$ ). At the neighbouring station no. 8 , situated on the crater's slope, juveniles of $E$. cordatum (6223 ind. $\mathrm{m}^{-2}$ ) dominated, making up $85.2 \%$ of total abundance and $97.5 \%$ of total biomass. In the centre of the crater (station 7) specimens of $E$. cordatum were smaller (mean individual weight of $0.03 \mathrm{~g}$ ) compared to those on the slope station, where two size classes occurred (11 and $1 \mathrm{~g}$ ). The mean individual weight $(8.8 \mathrm{mg})$ of $A$. filiformis was similar at both stations.

Table 3 presents a comparison between our data from July/August 1995 and those of the later investigation (September 1995) of Bischoff (1996). In September higher abundances of juveniles of A. filiformis and $\mathrm{Op}$ - hiura sp. occurred in the A. filiformis association area, while nearly the same numbers of adult $A$. filiformis and $E$. cordatum were found. Only juveniles of E. cordatum were more abundant in July/August.

\section{Discussion}

Comparability of methods

The multibox corer (Gerdes 1990) was deployed in the German Bight in 1995 for the first time in order to obtain up to nine simultaneous samples, each covering an area of $0.024 \mathrm{~m}^{-2}$. Due to the weight of the multibox corer, a deeper penetration into the sediment can be achieved compared to van Veen grabs (cf. Ankar 1977; Thatje and Gerdes 1997). However, we believe that this difference did not strongly influence the results of our study because most benthic species live in the upper 5 to $10 \mathrm{~cm}$ (Holme 1964; Kaplan et al. 1974) and juveniles near the sediment surface.

As sieving was done with a $0.5-\mathrm{mm}$ mesh, we probably lost many of the just-settled juveniles, especially polychaetes and bivalves (Bosselmann 1984; see Gerdes 1985). Therefore, we focus on the echinoderm fraction, which showed significant differences in abundance between the crater and its vicinity and which is the dominant taxon in the A. filiformis association (Salzwedel et al. 1985; Bischoff 1996; Thatje and Gerdes 1997).

\section{Present situation in the study area}

The North Sea is a marine shelf area with sediments consisting of high proportions of sand, mud, and mixtures of both (Figge 1981). These sediments are one of the most characterizing abiotic parameters for the benthic regime, especially in depositional zones like the Wadden Sea and in the inner German Bight (Eisma and Irion 1988). During this century several benthos studies have tried to provide insight into changes in the benthic community structures of the German Bight (Stripp 1969; Rachor and

Table 3 Comparison between the echinoderm age fractions of two investigations in summer/autumn 1995: Abundances (ind. $\mathrm{m}^{-2}$ ) in brackets

\begin{tabular}{|c|c|c|c|c|}
\hline & Amphiura-filiformis & & Crater & \\
\hline $\begin{array}{l}\text { Jul/Aug } 1995^{\mathrm{a}} \\
\text { Sept } 1995^{\mathrm{b}}\end{array}$ & $\begin{array}{l}\text { A. filiformis (adult) } \\
100 \%(35) \\
4.1 \%(34)\end{array}$ & $\begin{array}{l}\text { A. filiformis (juv.) } \\
0 \\
95.5 \%(793)\end{array}$ & $\begin{array}{l}\text { A. filiformis (adult) } \\
0\end{array}$ & $\begin{array}{l}\text { A. filiformis (juv.) } \\
100 \%(2594)\end{array}$ \\
\hline $\begin{array}{l}\text { Jul/Aug } 1995^{\mathrm{a}} \\
\text { Sept } 1995^{\mathrm{b}}\end{array}$ & $\begin{array}{l}\text { Ophiura sp. (adult) } \\
100 \%(166) \\
25 \% \text { (11) }\end{array}$ & $\begin{array}{l}\text { Ophiura sp. (juv.) } \\
0 \\
75 \%(35)\end{array}$ & $\begin{array}{l}\text { Ophiura sp. (adult) } \\
100 \% \text { (42) }\end{array}$ & $\begin{array}{l}\text { Ophiura sp. (juv.) } \\
0\end{array}$ \\
\hline
\end{tabular}

a Data of Thatje and Gerdes (1997; Table I, Annex)

b Data of Bischoff (1996; Tables I1; I3) 
Gerlach 1978; Salzwedel et al. 1985; Kröncke 1990, 1995; Rachor 1990a; Petersen et al. 1996; Thatje and Gerdes 1997). Such changes are caused by natural environmental variability, climatic trends, fishery activities (bottom trawling), eutrophication and pollution. Thatje and Gerdes (1997) showed again the trend of increasing abundance and biomass in the A. filiformis association and the whole inner German Bight due to eutrophication. Their study was performed after a long period without any disturbing natural events, such as severe winters or anaerobic conditions.

The investigated crater is situated on a main shipping route, and is thus rarely fished. The knowledge concerning sediment transport and resuspension in the German Bight is limited, but these phenomena are important processes in our study area, and especially in the crater. Sediment analysis together with the decrease in crater depth show that the crater acts as a sediment trap, concentrating dead and live particles in its surface sediments. Do these processes affect the benthic regime?

Comparison of data from August 1995 with the data of Bischoff (1996) showed that the mean densities of adult echinoderms outside the crater were comparable in both studies. The analysis of the macrofauna composition separates the crater stations from those of the surrounding A. filiformis association. Through the years the echinoderms have been the dominating faunistic element in the crater. Compared to the outside area, the sedentarian Lanice conchilega, normally occurring in dense patches in the vicinity, occurred only seldom and less abundantly in the crater. L. conchilega needs coarser sediments to build up its tubes (Lüneburg 1969), and such sediments are rare in the crater. Filter feeders such as bivalves with little ability to move, obviously, do not survive the high sedimentation rates in the crater, especially long-lived forms such as Mya truncata and Venus striatula, which were quite abundant in its vicinity. On the other hand, the crater traps larvae of many species, including those that are normally scarce in this area (cf. data of Thatje and Gerdes 1997).

The higher presence of juvenile echinoderms in the crater compared to its surroundings reflects concentration and enrichment effects. Survival rates of A. filiformis can be low and range between 3 and $10 \%$ after the first 9 months (Duineveld and van Noort 1986). Our data suggest comparably low survival rates: less than $10 \%$ of adult A. filiformis were found in April 1996 compared to the juvenile fraction in August 1995.

The ability of meroplanktonic larvae to move actively is rather limited; the distribution of larvae over greater distances is realized by transport by means of currents. Echino- and ophiopluteus larvae need between 4 and 9 weeks until settlement, depending on the environmental conditions. In the southern North Sea, echinoderm larvae reach highest abundances between June and July (Marshall 1948; Rees 1954), contributing up to about $80 \%$ to the whole meroplankton fraction (Rees 1954; Bosselmann 1984, 1989; Gerdes 1985). After metamorphosis many freshly settled forms can often be distributed on demersal drifters, as shown by Banse (1955) who observed metamorphosed ophiuroids behaving like zooplankton in layered water bodies of the Kiel Bight and in the Kattegat. The most important factor for successful recruitment of benthic populations through larvae is a suitable habitat. Cameron and Rumrill (1982) analysed the migration of larvae by the echinoderm Dendraster excentricus. They showed that the adults release a substance that makes the sediment attractive for larval settlement. The migration ability of juveniles that have settled on the sediment is also important for the distribution, which is at first, however, dependent on bottomnear currents.

The reasons for migration and drift are numerous and include biological interactions in the water column, as well as interactions between water column and seafloorinhabitating organisms (for further details we refer to McLaren 1963; Dooley 1977; Evans 1977; Dippner 1980). We assume passive transport combined with the sediment-trap function of the crater, to be most significant for the enrichment of meroplankton larvae. Crowe et al. (1987) showed that high densities of the brittlestar A. filiformis (2400 ind $\mathrm{m}^{-2}$ ), which are comparable to our densities in August 1995, may inhibit recruitment of many invertebrates, as the brittlestar predates on newly settled juveniles. The percentage of ingested juveniles depends on adult population density, which varies extremely in the crater (see Fig. 5). In general, more adult A. filiformis (168 ind. $\mathrm{m}^{-2}$ ) were found in the crater than in its vicinity and than in the whole A. filiformis area (cf. Bischoff 1996: 34 ind. $\mathrm{m}^{-2}$; Thatje and Gerdes 1997: 85 ind. $\mathrm{m}^{-2}$ ). In August 1995, juveniles of E. cordatum and A. filiformis contributed over $90 \%$ to the abundance in the crater. A. filiformis is known to profit from the early phase of eutrophication by increasing abundance, biomass (Duineveld et al. 1987) and even its size (Josefson and Jensen 1992; Josefson et al. 1993). The omnivorous Ophiura species, too, are assumed to influence recruitment by predation (Warner 1982; Volbehr 1995). Volbehr (1995) analysed the stomach contents of different size classes of Ophiura and showed a wide range of macrobenthic food particles, including animals such as bivalves, polychaetes, echinoids and phoronids.

Pearson and Rosenberg (1978) and, later, many authors like Rachor (1990b) and Heip (1995), described the effects of organic enrichment on the composition of benthic communities: high organic input leads to increasing biomass and abundance values, and after further increased eutrophication 'normal' species are replaced by opportunistic species with higher densities; and, finally, the sediments may become azoic. In the crater, A. filiformis, which is normally not known as an opportunistic species in the southern North Sea, is well adapted to the enrichment.

The nutrient increase in the crater, due to high sedimentation rates, changes the sediment structure and the species composition. Adaptive, mobile suspension and deposit feeders are able to cope with these changing environmental conditions. The enhanced organic input into 
the bottom sediments in the crater may also cause reducing conditions in the sediment, which firstly may affect some infauna, especially large, long-living bivalves. Such conditions might be further reasons for the specific community structure in the crater. Rhoads and Morse (1971) relate the disappearance of calcareous animals, such as echinoderms and bivalves, to extended periods of anaerobic respiration in dysaerobic environments, causing dissolution of calcium carbonate by accumulation of products of glycolysis or buildup of Ca-chelating metabolites, which we believe affects the crater's fauna, too. Periods of anaerobic conditions were never observed by us, but were shown in several studies for wide parts of the German Bight and the Baltic Sea in the early 1980s (see Rachor and Albrecht 1983; Gerlach 1984; Nelissen and Steffels 1988; Niermann et al. 1990).

\section{Conclusions}

The crater acts like a sediment trap, collecting seston and metamorphosed larvae at its bottom. Adaptive, non-filtering suspension feeders were found regularly, and dominated in the crater. The mean densities of these species are higher in the crater than in the surrounding $A$. filiformis area, due to enrichment of juveniles. The high sedimentation rates in the crater support the view of increased benthic-pelagic coupling.

Acknowledgement We acknowledge the support of the crews of the RV's 'Victor Hensen' and 'Wega' during our work at sea.

\section{References}

Ankar S (1977) Digging profile and penetration of the van Veen grab in different sediment types. Contr Askö Lab, University of Stockholm, 16:1-22

Banse K (1955) Über das Verhalten von meroplanktischen Larven in geschichtetem Wasser. Kieler Meeresforsch 11:188-200

Bischoff C (1996) Das Makrozoobenthos schlickiger Böden in der Deutschen Bucht im Vergleich zu früheren Untersuchungen. Diplom-Arbeit University of Bonn, $76 \mathrm{pp}$

Bosselmann A (1984) Untersuchungen zur Verteilung von Zooplankton in der zentralen Nordsee und der Deutschen Bucht unter besonderer Beachtung des Transportes von Meroplankton. Diplom-Arbeit University of Bochum, $85 \mathrm{pp}$

Bosselmann A (1989) Larval plankton and recruitment of macrofauna in a subtidal area in the German Bight. In: Ryland JS, Tyler Pa (eds) Reproduction, genetics and distributions of marine organisms. Olsen and Olsen, Fredenberg, pp 43-54

Cameron RA, Rumrill SS (1982) Larval abundance and recruitment of the Sand Dollar Dendraster excentricus in Monterey Bay, California, USA. Mar Biol 71:197-202

Clarke KR, Warwick RM (1994) Change in marine communities: an approach to statistical analysis and interpretation. Natural Environment Research Council, Plymouth, 144 pp

Crowe WA, Josefson AB, Svane I (1987) Influence of adult density on recruitment into soft sediments: a short-term in-situ sublittoral experiment. Mar Ecol Prog Ser 41:61-69

Dippner J (1980) Numerische Simulation horizontaler Verdriftung vertikal wandernder Zooplankter. Mitt Inst Meeresk Univ Hamburg 23:61-113

Dooley HD (1977) The long-term transport of diurnally migrating plankton. ICES, CM C:24
Duineveld GCA, van Noort GJ (1986) Observations on the population dynamics of Amphiura filiformis (Ophiuroidea: Echinodermata) in the southern North Sea and its exploitation by the dab, Limanda limanda. Neth J Sea Res 20:85-94

Duineveld GCA, Künitzer A, Heyman RP (1987) Amphiura filiformis (Ophiuroidea: Echinodermata) in the North Sea. Distribution, present and former abundance and size composition. Neth J Sea Res 21 (4):317-329

Eisma D, Irion G (1988) Suspended matter and sediment transport. In: Salomons W, Bayne BL, Duursma EK, Förstner U (eds) Pollution of the North Sea. Springer, Berlin Heidelberg New York, pp 20-35

Evans GT (1977) Biological effects of vertical-horizontal interaction. Deep-Sea Res 24:931-936

Figge K (1981) Sedimentverteilung in der Deutschen Bucht. 1:250,000. Karte Nr. 2900. Dtsch Hydrogr Inst, Hamburg

Gerdes D (1985) Zusammensetzung und Verteilung von Zooplankton sowie Chlorophyll- und Sestongehalte in verschiedenen Wassermassen der Deutschen Bucht in den Jahren 1982/83. Veröff Inst Meeresforsch Bremerhaven 20:119-139

Gerdes D (1990) Antarctic trials with the multibox-corer, a new device for benthos sampling. Polar Rec 26:35-38

Gerlach SA (1984) Oxygen depletion 1980-1983 in coastal waters of the Federal Republic of Germany. Ber Inst Meeresk Kiel 130:1-87

Hagmeier A (1925) Vorläufiger Bericht über die vorbereitenden Untersuchungen der Bodenfauna der Deutschen Bucht mit dem Petersen-Bodengreifer. Ber Dtsch Wiss Komm Meeresforsch 1:247-272

Heip C (1995) Eutrophication and zoobenthos dynamics. Ophelia $41: 113-136$

Holme NA (1964) Methods of sampling the benthos. Adv Mar Biol 2:171-260

Josefson AB, Jensen JN (1992) Growth patterns of Amphiura filiformis support the hypothesis of organic enrichment in the Skagerrak-Kattegat area. Mar Biol 112:615-624

Josefson AB, Jensen JN, Ærtebjerg G (1993) The benthos community structure anomaly in the late $1970 \mathrm{~s}$ and early $1980 \mathrm{~s}-$ a result of a major food pulse? J Exp Mar Biol Ecol 172: $31-45$

Kaplan EH, Welker JR, Krause MG (1974) A shallow water system for sampling macrobenthic infauna. Limnol Oceanogr $19: 346-350$

Kröncke I (1990) Macrofauna standing stock of the Dogger Bank. A comparison: II 1951-1952 versus 1985-1987. Are changes in the community of the northeastern part of the Dogger Bank due to environmental changes? Neth J Sea Res 25:189-198

Kröncke I (1995) Long-term changes in North Sea benthos. Senckenberg Marit 26:73-80

Lüneburg H (1969) Sedimenthabitus und Sedimentdynamik in Pieprinnen vor Büsum und im Hörnum-Tief vor Sylt (Deutsche Bucht). Veröff Inst Meeresforsch Bremerhaven 11:137-164

Marshall NB (1948) Continuous plankton reports: Zooplankton (other than Copepoda and young fish) in the North Sea 1938-1939. Hull Bull Mar Ecol 2(13):173-213

McLaren IA (1963) Effects of temperature on growth of zooplankton, and the adaptive value of vertical migration. J Fish Res Bd Can 20:685-727

Müller G (1964) Methoden der Sedimentuntersuchung. Teil I. Sediment Petrologie. Schweizerbach, Stuttgart, 303 pp

Nelissen PHM, Steffels J (1988) Eutrophication in the North Sea NIOZ Rep 1988-1984, pp 1-100

Niermann U, Bauerfeind E, Hickel W, Westernhagen $\mathrm{H}$ von (1990) The recovery of benthos following the impact of low oxygen content in the German Bight. Neth J Sea Res 25: 215-226

Oebius HU (1983) Laboratory and insitu bed shear stress measurements. In: Sumer B, Mueller A (eds) Mechanics of sediment transport. Balkema, Rotterdam, pp 243-254

Pearson GCJ, Rosenberg R (1978) Macrobenthic succession in relation to organic enrichment and pollution of the marine environment. Oceanogr Mar Biol 16:229-311 
Petersen GH, Madsen PB, Jensen KT, Bernem KH van, Harms J, Heiber W, Kröncke I, Michaelis H, Rachor E, Reise K, Dekker R, Visser GJM, Wolff WJ (1996) Red list of macrofaunal benthic invertebrates of the Wadden Sea. In: von Nordheim H, Andersen ON, Thissen J (eds) Red list of biotopes, flora and fauna of the trilateral Wadden Sea area 1995.Helgoländer Meeresunters. 50:69-76

Rachor E, Gerlach SA (1978) Changes of macrobenthos in a sublittoral sand area of the German Bight 1967-1975. Rapp Pv Réun Cons Int Explor Mer 172:418-431

Rachor E, Albrecht H (1983) Sauerstoff-Mangel im Bodenwasser der Deutschen Bucht. Veröff Inst Meeresforsch Bremerh 19:283-293

Rachor E (1990a) Changes in sublittoral zoobenthos in the German Bight with regard to eutrophication. Neth $\mathbf{J}$ of Sea Res 25:209-214

Rachor E (1990b) Veränderungen der Bodenfauna. In: Lozán JL, Lenz W, Rachor E, Watermann B, v. Westernhagen H. Warnsignale aus der Nordsee. Hrsg. Parey, Berlin, pp 158-165

Rees CB (1954) Continuous plankton records: The distribution of echinoderm and other larvae in the North Sea 1947-51. Hull Bull Mar Ecol 4(28):47-67

Reineck HE, Dörjes J, Gadow S, Hertweck G (1968) Sedimentologie, Faunenzonierung und Faziesabfolge vor der Ostküste der inneren Deutschen Bucht. Senckenberg Leth 49:261309

Rhoads D, Morse W (1971) Evolutionary and ecologic significance of oxygen-deficient marine basins. Lethaia 4:413428

Salzwedel H, Rachor E, Gerdes D (1985) Benthic macrofauna communities in the German Bight. Veröff Inst Meeresforsch Bremerh 20:199-267

Stripp K (1969) Jahreszeitliche Fluktuationen von Makrofauna und Meiofauna in der Helgoländer Bucht. Veröff Inst Meeresforsch Bremerh 12:65-94

Thatje S, Gerdes D (1997) The benthic macrofauna of the inner German Bight: present and past. Arch Fish Mar Res 45: 93-112

Volbehr U (1995) Zur Ökologie und Vergesellschaftung von Pariambus typicus (Crustacea, Amphipoda) und OphiuraArten (Echinodermata, Ophiuroidea) in der Deutschen Bucht. Diplom-Arbeit University of Heidelberg, $118 \mathrm{pp}$

Warner G (1982) Food and feeding mechanisms: Ophiuroidea. In: Jangoux M, Lawrence JM (eds) Echinoderm nutrition. Balkema, Rotterdam, pp 164-184

Communicated by H.-D. Franke 